\title{
Palestine: \\ Reconciliation and Peacebuilding. Perspectives from the Civil Society Organizations
}

\author{
Ayman YOUSEF \\ Sezai ÖZÇELIKK
}

\begin{abstract}
This research paper aims to shed light on the theoretical perspectives and operational approaches adopted by the Palestinian civil society organization in connection with the peacebuilding and reconciliation process in the Palestinian context. The research question is what are the different moves, debates, and initiatives taken by the Palestinian civil society organizations to put an end to the conflict? Why could not they succeed or produce tangible results in fulfilling this goal? The first part of the paper considers debates, contexts, and developments of civil society organizations, in general, and Palestine, in particular, as well as their roles on political, national, cultural, and developmental levels. Civil society deepens its peaceful intervention in many developed and developing countries to build domestic peace and achieve reconciliation, along with other tasks and duties. Palestine's case is not an exception but a unique case since the independent sovereign state of Palestine does not exist on the ground. The second part aims to deeply analyze the roles of civil society in the reconciliation process and to assess why this process failed to produce fruitful results until now. To use narrative methodologies, the paper collects primary data through structured interviews and the focus group. Interviews were conducted with

Ayman YOUSEF

Arab American University, Palestine

E-mail: ayman_yousef@yahoo.com

\section{Sezai ÖZÇELİK}

Çankırı Karatekin Üniversitesi, Turkey the cadres and activists in the Palestinian civil society and other professionals and experts in this field. The last part concludes that civil society, especially among the youth, is necessary for reconciliation not only between Israeli and Palestinians but also within the Palestinians as well.
\end{abstract}

E-mail: sezaiozcelik@gmail.com

Conflict Studies Quarterly

Issue 35, April 2021, pp. 89-109

DOI: $10.24193 / \mathrm{csq} .35 .6$

Published First Online: 05 April /2021
Keywords: Civil Society, Peacebuilding, Israel, Palestine, conflict. 


\section{Introduction}

Throughout the last century, Palestine was under the control of several colonial powers and hegemonic forces, including the current Israeli occupation. In 1948, a new phase of suffering began with a catastrophic loss ( $A n-N a k b a)$, ending up with the Israeli army occupying part of the land. What followed was another catastrophe (Al-Naksa) which occurred in 1967, which ended with the loss of entire Palestinian lands to the Israeli occupation who have been exposing them to several human rights violations. $15^{\text {th }}$ May 1948 it is considered the most tragic date in contemporary Palestinian history as more than 428 villages were destroyed and more than 800,000 Palestina civilians were forced to leave their land and property (Palestine Liberation Organization Negotiation Unit, 2018). After losing the entire land, the Palestinian community took the lead in defending the lands through popular resistance, using both armed and unarmed resistance strategies. In this context, the Palestinian civil society played a key role in developing and implementing the national agenda through a mechanism of coordination among families, village councils, popular committees, charitable societies... etc. All these entities had a role in minimizing the damages that resulted from the "Israeli" occupation and the subsequent wars caused at that time. Thus, the Palestinians were forced to organize themselves to face the new harmful situation and to preserve their national identity that was under attack (Falcitelli \& Montanarini, 1999).

In 1987, the First Intifada erupted with a large scale mass participation (Ogretir \& Ozcelik, 2017). It lasted for four years until the Oslo accords were signed in 1993. Despite the terrible circumstances, civil society grew and developed further to keep up with the changes that occurred on the political, economic, and social levels. One of these changes was the rise of the Palestinian Authority as the national body for the first time in Palestinian history. However, the specific role of the civil society organizations at that stage was directed at serving the Palestinian people and filling the gaps within the newly created Palestinian Authority by acting as a watchdog on the Authority itself and by representing the demands and the rights of the marginalized sections in the Palestinian society. As systemic processes, peacebuilding and reconciliation have become an inevitable necessity in Palestine following the political split and the geographical fragmentation that occurred in 2007. Indeed, in the age of liberal globalization, nobody can imagine any real developments or democratization without adequate positive interventions by civil society. Of course, Palestine has gained momentum since it is a conflict zone. It is not only a nation under occupation, but also fragmented and divided people and territories.

Two major parties dominate the Palestinian politics. One of them is Fatah (The Palestinian Liberation Movement) and Hamas (The Islamic Resistance Movement). The former was founded by Yasser Arafat in the 1950s and has been at the head of the Palestinian national movement, whereas the latter was founded in 1987 as a moderate 
political Islam movement intended and committed to establishing an Islamic state in Palestine. Hamas in its Charter defines itself as a local Muslim Brotherhood branch in Palestine. The movement has a comprehensive and macro Islamic approach to life, the universe, politics, culture, and economics"1.

Significantly, in the absence of real political alternatives, Hamas and Fatah have continued to monopolize the political landscape in the West Bank and Gaza, particularly if we realize that the Palestinian leftist groups and factions lost their political influence with the collapse of its Soviet supporter in the last three decades. Hence, the different ideologies of the two dominant parties resulted in different approaches for dealing with the Israeli occupation.

In the summer of 2006, the Palestinians held a parliamentary election in the troubled and uncertain political environment. This election resulted in the victory of Hamas due to several political issues. First, the Palestinian Authority has been unable to govern Gaza effectively after Israel disengaged from its territory in 2005. Secondly, after the death of Arafat in 2004, Fatah was internally struggling and overwhelmed with several allegations of corruption, cronyism, a weak economy, high unemployment rates, and ineffective preventive security forces (Pina, 2006).

Also, Fatah's lack of electoral success was due to the lack of unity within this political faction and due to the inability to speak with one voice after the death of Arafat. Fatah was unable to agree on the composition of its national list and registered multiple lists just before the deadline, December 14, 2005. Whereas Hamas offered one candidate in each electoral constituency, Fatah ran several candidates in the same constituency. Consequently, support for Fatah candidates was divided, while the supporters for Hamas focused on one candidate. It was evident that Fatah underestimated the popularity of Hamas and the significance of its political challenge (Pina, 2006).

Naturally, the consequence was an overwhelming electoral victory for Hamas and its supporters who marched through Ramallah streets, holding Hamas slogans and waving green flags. When they raised their green flag over the Palestinian Legislative Council building, Fatah supporters who provoked by this act, tried to remove the banner. With this incident, the internal struggle began in the streets of the Gaza strip and tension rose in West Bank. Both sides started to throw stones and fight with each other until the Palestinian Authority security forces fired warning shots into the air. For months following the election, the tension between the two groups remained high (Schanzer, 2008).

After winning the election, Hamas had the responsibility of power and international scrutiny for the first time but neither Israel nor the major world powers, including the US and the EU, recognized the new Palestinian government. Fatah refused to hand over

1 See Hamas Charter in Arabic: https://www.palestine-studies.org/sites/default/files/mdf-). 
the wheels of power nor to join a new Hamas-led coalition, while Hamas insisted that its electoral victory had granted it a legitimate control over the Palestinian Authority. This situation created significant tensions between the two parties. Incidents of open violence between them led to dozens of deaths, particularly in the Gaza Strip. Moreover, due to several oppositions against Hamas at that time, the economic situation was deteriorating and the PA failed to pay the salaries of its employees (Schanzer, 2008).

In June 2007, the armed forces of Hamas took over Gaza in what was described as a "liberation". After six days of ongoing fighting, the entire Gaza Strip was under Hamas's control. The Palestinian Authority President and Fatah leader, Mahmoud Abbas, then dismissed the Hamas-led government, and a new emergency cabinet had been founded in the West Bank, led by Prime Minister Salam Fayyad (Schanzer, 2008).

This wave of violence was a milestone in Palestinian history and a massive setback in the struggle against the Israeli occupation. It was the first time that the Palestinians were engaged in open warfare against one another. However, it should be noted that since the beginning of the division, there have been several reconciliation attempts. The first agreement was signed in May 2011, and another one in 2012. However, in March-April 2012, the political crisis was reignited and tensions strongly increased in 2013. Again, in April 2014, Hamas and Fatah raised the hope of the Palestinians by signing a new national reconciliation deal, and finally forming a unity government in June 2014. However, the terms of the agreement were not implemented; therefore, it could not reduce the tension between the two factions. Indeed, Gaza remained under Hamas's control and the West Bank under Fatah's.

This Palestinian internal political split made the situation even more complicated. Hence, the Palestinian civil society has to carry the burden of dealing with both situations created by the occupation and the political split. Therefore, the main reason behind the creation of the civil society organizations (CSOs) was to strengthen the internal abilities of the Palestinian people to manage the occupation and ramifications of the political fragmentation in a much better strategy and visionary approach. Primarily speaking, the task of CSOs is to rescue and support the specific field of their responsibility and under their mandate For example, some organizations have the mandate to work on women's rights; others address children's rights; while other organizations are focused on democratization, human rights, social accountability, and reconciliation (Bari, 1999). These organizations have achieved moderately in the issues of human rights, democratic transformation, and national reconciliation for many internal and external reasons and factors.

Significantly, the political split between Fatah and Hamas constituted a prominent challenge to the civil society and Palestinians in general. In the light of the internal political fragmentation and the deterioration of the surrounding Arab political order in the context of the Arab Spring, the Palestinian Question returns to be examined in 
regional blocks and international alliances and hubs. This split had not only weakened the Palestinian political project but also it increased negative implications to people's resilience and stead fastness. The CSO warned of the risks of the political division and its repercussions and therefore endeavored to achieve national reconciliation. They conducted and tailored dialogues with the participation of various Palestinian political forces and adopted a wide range of activities and initiatives in this regard (Sheikh Khalil, 2008).

\section{Civil Society, Peacebuilding and Reconciliation in Theoretical Context}

The modern idea of civil society can be traced back to Tocqueville (1805-1859) that emphasized the importance of independent and voluntary associations (De la Democratie en Amerique). He defines these associations as schools of democracy in which democratic attitudes, behavior, and thinking are learned so that citizens can be protected from authoritarian regimes and defend their rights against tyrannical majorities in society. According to Tocqueville, these associations should be created on all levels (local, regional, national) voluntarily (Wilde, 2014). Civil society is a part of social capital and civic virtues such as trust, honesty, acceptance, and tolerance. The essential components of social capital are reciprocity, trust, and networks of civic engagement that is a society characterized by people who are willing to do things for others, not for immediate return, but with the confidence that others would do the same for them. The idea of social capital can be traced back to the concept of the fraternity of the French Revolution (Putnam, 2000). The important dimension of civil society is the relationship with the state in the context of democracy. Since democracy is closely related to accountability and public opinion, civil society is an important tool for mobilizing public opinion and making government accountable.

The democratization in the Middle East and North Africa (MENA) has reached its climax during the Arab Spring. The struggle between tradition and modernity together with the high level of unemployment, regional conflicts, semi-autocratic governments, and the pervasion of clientelism and neo-patrimonialism in state structure has led to a weak, fragile, and artificial civil society in the region (Natil, 2019). Civil society is an important part of peacemaking, conflict resolution, and state-building. It is an alternative and a supplement to diplomatic Track I efforts. It provides an externally driven agenda for real social change on the ground in conflict settings (Ogretir, 2017a, 2017b).

The idea of civil society, NGOs, and civil initiatives has been grown in the Palestinian territories. During the 1970s and 1980s, the PLO and its factions have established most civil society organizations. Their main area of activities has concentrated on resisting the Occupation and establishing an independent Palestinian state. The Palestinian NGOs in Gaza Strip and the West Bank began to thrive in the 1990s especially after the Palestinian Authority was established and recognized widely in the world in 1994. The 
road to statehood in Palestine has increased NGOs' abilities to obtain funds from all over the world. Although foreign donations have been pouring into the Territories, it has made the NGOs very dependent on external funding. As a result, they have become more vulnerable to any external pressures.

In 2000, there were approximately 1500 civil society organizations and that number has reached 1495 in 2007 in Palestine. Almost 69 percent were located in the West Bank. The rest of it (31\%) were in the Gaza Strip. The average number of paid workers in the NGOs was 20 persons per organization. The most important statistic is that 55 percent of paid workers were women. Although the number of NGOs has increased during this period, the number of volunteers was decreased from 64,936 in 2000 to 53,622 in 2007. The research has also given information about funding that 64 percent of the money for NGOs received from external sources, 4 percent from the Palestinian citizens of Israel, and the rest from the organizations' activities and local communities or institutions. The amount of funding is doubled between 1999 and 2006 is from nearly \$ 113 million in 1999 to \$ 224 million in 2006 (Chaitin, 2011).

The liberal peace theory that combines democracy and civil society has become an important cornerstone in peacebuilding. The roots of liberal peace could be traced back to Kant and his Perpetual Peace that show direct causation between the adoption of democracy and the ending of the war. The democratic peace theory claims that democratization is an important tool for building liberal peace. As a result, peacebuilders have attempted to turn conflict-ridden societies and war-torn states into liberal democracies (Bouris, 2014).

In September 2015, the United Nations General Assembly (UNGA) approved 17 Sustainable Development Goals (SDGs) for 2016-2030. The new development agenda is framed in "Five Ps": people, planet, prosperity, peace, and partnership. The SDG number 16: "Promote peaceful and inclusive societies for sustainable development, provide access to justice for all and build effective, accountable, and inclusive institutions at all levels. UNGA must have linked peacebuilding and Civil Society Organizations (CSOs) that ensure a peace goal in the SDGs. Civil society and peacebuilding are both widely debated concepts. Peacebuilding is related to the concept of conflict transformation described as changing conflict into something constructive (Lederach, 1995). Peacebuilding aims at preventing and managing armed conflict and at creating sustainable peace after largescale organized violence has ended (Paffenholz, 2010). Peacebuilding and civil society are interconnected and complex processes. Civil society in peacebuilding is based on "bottom-up" rather than "top-down" approaches and local ownership of peacebuilding processes. It promotes building national unity and reconciliation through grassroots traditional processes.

Since the early 1990s, there has been a proliferation of global recognition of the civilsociety actors' contributions. One of the examples is the 1992 Nobel Peace Prize for 
Guatemalan indigenous woman peace-activist Rigoberta Menchu Tum. Menchu received the Nobel Peace Prize, "in recognition of her work for social justice and ethno-cultural reconciliation based on respect for the rights and indigenous people" (NobelPrize.org, 1992). There are some civil society organizations and campaigns that also received the Nobel Peace Prize: The International Campaign to Abolish Nuclear Weapons (2017), Grameen Bank (2006), International Campaign to Ban Landmines (1997), Pugwash Conferences on Science and World Affairs (1995), and International Physicians for the Prevention of Nuclear War (1985).

Civil society organizations ( $\mathrm{CSO}$ ) view peacebuilding as bridging polarized groups and promoting dialogue and reconciliation. CSOs' peacebuilding activities are as follows: Advocacy and training for human rights, production of reconciliatory information, the encouragement of politicians for peace politics, and training programs for disadvantaged groups. Because peacebuilding is a process, CSOs may focus on a set of activities in governance, human rights, reconciliation, and development that aims at prevention, mitigation, and resolution of conflict (Leeuwen, 2009).

There is a close link between civil society peacebuilding and international non-governmental organizations (NGOs), intergovernmental organizations, and donors. First, international stakeholders may support local civil society via new approaches for conflict resolution and peace capacity building training. Second, international organizations provide development assistance as well as technical and political civil society support.

In the mid-seventies, Johan Galtung developed peacebuilding as a technical term. In his quest to develop a new concept, Galtung considers peacebuilding inapplicable in real conflict situations unless we deal with the causes at the root of violence. Hence, peace-building structures must be constructed in a way to promote suitable peace and to enhance applicable peace management and conflict resolution (Galtung, 1976). Another school of thought looked upon peacebuilding as an actual process aiming at strengthening national capacities and managing conflicts peacefully while matching sustainable peace with justice and development (UN Report on Peacebuilding, 2017). However, it is challenging to shed light on peacebuilding unless we link it to some overarching terminologies such as conflict transformation, restorative justice, healing, dealing with the past, reconciliation, forgiveness, and national unity. This can be considered a bottom-up approach for peacebuilding through encouraging decentralized social, economic, and cultural structures to shift the relationships of coercion to connections of comfort and social harmony (Galtung, 1969).

Peace is considered to be the hardest point to fulfill since it requires intensive work between the conflicting factions, groups, or communities. Following a logical order, peacebuilding develops gradually after the two stages, namely peacemaking and peacekeeping. These two stages are crucial for ending bloody conflicts that can provide convenient platforms for more effective peacebuilding strategies in later stages (Ghali, 
1992). The vast literature in the field of peace studies focuses on five consecutive stages to establish peace in much more practical and tangible terms. First, dealing with the root causes of conflicts; second, appropriate dealing with community's expectations; third, establishing an extensive network of national and international organizations; fourth, harmonizing the national and international interests and finally matching the above-mentioned stages with peacebuilding².

It is noted that the theoretical components of this concept indicate that peacebuilding is not only a post-conflict resolution or a post-accord construction, but it is a more comprehensive strategic umbrella that encompasses all arrays of processes, approaches, stages, and activities that can contribute to transforming the conflict into a more sustainable peaceful relationship. In other words, this term can be perceived to have transformational nature and a process of changing the negative relationships into more positive, constructive attitudes in the long run (Lederach, 1995). Therefore, Lederach proposed a sort of mechanism to strengthen peacebuilding on the grounds by engaging the grassroots, local NGOs, and other national and international actors to create conditions conducive to the peace process (Lederach, 2005: 203).

The concept of reconciliation is best described by Bloomfield et al. (2008) who observed that reconciliation is both a goal and a process. So, we have to take into consideration a clear answer to the following question: How can we recognize when the goal of reconciliation has been achieved? Of course, it is not easy to answer such a question since reconciliation is not a handy roadmap and there are no bypass roads or easy descriptions for the reunifications. These societies have been divided by long-lasting violence that resulted from conflicts. Thus, there is a need for a wider understanding as well as a conciliatory environment as a base for those conflicted parties. We have the difficult challenge of establishing a new form of positive co-existence. Accordingly, others have defined the term "reconciliation". For example, Galtung states that it means closure plus healing; closure in the sense of not re-opening hostilities, healing in the sense of being rehabilitated (Galtung, 2001).

Working at the political $\backslash$ elite level is crucial to achieving reconciliation, but that arrangement remains incomplete unless we integrate the social $\backslash$ communal reconciliation into the process. Civil society, in this regard, can facilitate integrating communities into a more meaningful process of reconciliation with justice, social harmony, and active citizenship the main driving principles on the ground (Wüstenberg, 2009).

2 Peace-making - Overview Conflict Management Toolkit. (Johns Hopkins University, School of Advanced International Studies, Conflict Management Program). Accessed on 15 Feb. 2006. Available from http://legacy2.sais-jhu.edu/cmtoolkit/approaches/peacemaking/index.htm 


\section{Civil Society in the Palestinian Context}

In his theory of hegemony, Antonio Gramsci describes how states use cultural institutions to maintain power in capitalist societies. Gramsci does not understand the 'state' inthe narrow sense of a government. Instead, he perceives two different ways of how the ruling class maintains its dominance in society: first, it use a coercive strategy that employs the political society (army, the police, legal systems, etc.) of a capitalist state to force other classes to accept its role. Second, they apply a hegemonic strategy that uses the civil society's (family's, education systems', trade unions', etc.) ideas and values to persuade the subordinate class of the idea that the rule of the capitalists is legitimate and fruitful (Özçelik, 2005). The civil society organizations are commonly seen as the 'private' or 'non-state' sphere that mediates between the state and the economy in this Gramscian paradigm (Ncube, 2000).

The debate on the position of the Civil Society and the expected role in the efforts of national reconciliation between the two main Palestinian parties (Fatah and Hamas) has become the main argument among the Palestinians at all Micro and Macro levels. This development comes along with the need to frame the potential use of the political position of Palestinian Civil Society through scientific studies to accumulate the efforts to achieve national, political, developmental, and socioeconomic goals.

The combination of both our professional background and accumulated experience has expanded the idea of this research, putting additional motivation on the importance of the Palestinian Civil Society's role in activating the internal political situation. Indeed, this important issue affected the holistic Palestinian public life in different areas: economic, social, political... etc. It is noted that the strong presence of different Palestinian civil society organizations highlights the great importance of their role in peacebuilding actions internally and externally at the local and elite levels. This study came along with the passion for achieving peace, prosperity, and stability within the Palestinian society and with other neighboring communities. The idea of the accumulated knowledge of the Palestinian civil society has fundamentally contributed towards solidifying public life and enhancing the socio-economic formation of the Palestinian context. The Palestinian civil society has a particular structural role in Palestinian public life. Thus, this paper highlights the main areas that determine the future of civil society's contribution to the Palestinian political map.

Since the end of the Cold War, the Middle East or the Israel-Palestine peace process have been the most important peacebuilding project in the world. The Palestinians, Israelis, and peace sponsors have mostly based on the realist-liberal conceptions of conflict resolution between sovereign entities and democratization. Apart from the Israel-Palestine conflict, there has been intense internal conflict within the Palestinian people. As a result, the Palestinian society seems not to have a unified government that combines both the Islamist Hamas and secular Fatah political parties. Hamas may seem 
to have transitioned from militarism to governance and become a resistance movement. This transition has created a new area of civil society building in Palestine society.

The real peace process in the Middle East in general and the Israeli-Palestinian conflicts, in particular, requires the integration of bottom-up (civil society, second-track diplomacy, grassroots) peacebuilding activities and top-down (governmental, formal) peace negotiations and binding treaties. Without people-to-people peacebuilding, the binding agreements among elected leaders have not ensured the conflict to come to an end. Since the end of the Cold War, there has been increasing international recognition of the contributions of civil society and grassroots actors make to peace in the Israeli-Palestinian conflict that has mostly seen as the intra-state nature and mostly affected civilian population. The distinction among soldiers, rebels, and civilians has largely disappeared. In an intra-state conflict environment, diplomatic (conventional) mechanisms for conflict resolution and peacemaking lost their relevance. Also, the collapse of the Soviet Union has led to a new freedom for international NGOs to operate in conflict zones. It is important to note that civil society cannot be the only tool for the peaceful resolution of conflicts but diverse civil society initiatives such as media, churches, human rights networks, peace groups, development organizations, women's associations, community and religious leaders, educational institutions, trade unions, and professional associations may have indirect influences on political peace processes (Leeuwen, 2009).

Political agreements usually do not lead to a peace that must be made between people. As a result, there is a need to develop positive and negative peace beyond the political arena. Civil society helps to create environments that make collaborations possible and nurture them and allow them to evolve. Thus, civil society is essential for producing the necessary social and cultural understanding for lasting peace. The collaborations between the Palestinian and Israeli people are necessary for the basic motivation of stable peace. The endless accusation of past mistakes and the egoism of victimization produce blame, guilt and comparisons match between conflicting parties.

From the Israeli point of view, Israelis have been suffered since the Exodus and it has reached its climax during the Holocaust. They have seen themselves as the only victim of the conflict. They also dehumanize and delegitimize the opposite conflict parties, namely the Palestinians, called sub-humans, animals, drugged cockroaches, grasshoppers, two-legged beasts, demons, bloodthirsty devils, deviates, parasites, psychopaths, and violence-prone (Moughrabi, 1992). On the other hand, the Palestinians and even almost whole world have perceived the İsrael as a Zionist and occupied state that has produced huge suffering since its establishment in 1948 which called asAl-Nakba (Arabic: ابككن ال the Catastrophe) as a chosen trauma. As a victim, they have traumatized and suffered from insecurity, anxiety, and sadness. During the de-Arabization period, almost 420 villages were destroyed, Arabic names of neighborhoods and streets were 
replaced with Jewish names and Hebrew became the main language of the country and Hativka-Israel's national anthem (Chaitin, 2012). The psycho-analytical and psychodynamic concepts such as group narcissism, projection, ethnocentrism, stereotype, prejudice, dehumanization, discrimination, and egoism of victimization have played crucial roles in the Israeli-Palestinian conflicts (Ogretir \& Ozcelik, 2008).

At present, civil society institutions work primarily to enhance peace by providing people with knowledge and skills. Nobody can deny that civil society plays a role in consolidating and disseminating knowledge related to democracy, human rights, and development. At the same time, they promote skills connected with conflict transformation, negotiations, mediation, and effective communication. The Palestinian grassroots movements aim to raise awareness of the Palestinian cause that views Israel as an occupier in their historical narratives (Özçelik, 2017). The final goal of such a mission is to promote people's resilience by encouraging them to resolve their local differences peacefully and by adopting the strategy of sustainable development, especially in those areas closer to the Wall and the Israeli settlements in West Bank. Such techniques are helpful not only to strengthen peaceful coexistence internally but also to encourage local communities to have a say in resolving national as well as local conflicts including that one between Fatah and Hamas. For instance, Taawon for Conflict Resolution is a local Palestinian civil society organization that has been engaged in such activities in the last ten years. Taawon is working with youth, women, and the weaker sections of the society and it has widely published reports and studies, along with organizing seminars and workshops to promote these values.

There were some initiatives embraced by civil society organizations in Palestine to eliminate the internal hostility. Such role was crystalized on the ground by stimulating middle-class leaders from both factions (Fatah and Hamas) to meet face to face and to exchange views on the future of reconciliation. Mustafa Al Barghouthi from Al Mobadara has been optimistic about the future role of civil society in bridging the gaps between Fatah and Hamas, although in some of his interviews he indicated that there are some hindrances on the way to reconciliation. To have more concrete results on the ground, Al Barghouthi would rather suggest an alliance or solid network between civil society groups and the communal mobilization to precipitate change. In much microanalysis, Palestinian society needs intra-personal reconciliation as both communities and individuals need to reconcile with themselves.

According to Walid Salem, an activist and academic as well, civil society institutions are generally expected to fulfill their roles. These roles include monitoring violations of human rights; observing elections; raising public awareness of democracy, human rights, gender issues, providing agricultural and health information, international lobbying, and organizing nonviolent activities to protest against the occupation and social domination (personal communication). In the same context, Athar Zaghal from UN women, 
says that the role of civil society, in general, is to work as an advocacy tool, to advocate people's and the society's voice and put pressures on the official authorities. It is also a monitoring tool that the government uses to guarantee a social, administrative and political system that is free from violations and corruption (personal communication, 15.12.2017).

These roles are justified as part of these organizations' missions to move towards building a healthy Palestinian society and mobilizing the foundations of its existence, survival, and development. Human Rights and Democracy Media Center SHAMS, for example, defines its vision as building a civic democratic society based on tolerance, justice, and rule of law. There is a widespread belief that civil society represents the values of tolerance, recognition, assimilation, reconciliation, democracy, and amnesty. Civil society has a history associated with politics, economics, and developing the state and society. It can facilitate the real intellectual and cultural process towards citizenship and democracy with justice, equality, and basic freedoms as the main principles and slogans (Bishara, 2012).

Moreover, they work on creating media pressure on the international community to make a change. That is why they focus on covering incidents of people who live in crucial and critical situations and broadcasting them to the world. As Amal Joumah from the Women Affair Technical Committee stresses, the NGOs have to play an important role in bringing people's attention to the issues happening around them. This can be done through the coverage and reach out, using media, communication and advocacy campaigns more particularly in issues connected with women in Palestinian society and their daily routine problems (personal communication, 1.1.2017).

Due to the absence of the Palestinian Authority, the intervention of external actors was necessary. Considering that the Palestinians' partial loss of hope in the newly constructed arrangements that took place after the Oslo Accords in 1994, the measurements by external institutions have further consolidated Therefore, people can feel that they have something to lean on since the game has taken place and the third wheel has interfered under the umbrella of the CSOs in Palestine. Since then the organizations have interfered as a third party that has supported the Palestinian people and offered aid when other authorities have failed to help. However, violence has never stopped. Considering Gramsci's theory, it is apparent how powerful forces use civil society to spread their control by containing people's pain and suffering at the end of the day.

Different field interviews have been conducted by the researcher to measure the impact of civil society interventions in the domestic reconciliation process. Ayed Abu Eqtaish, the Accountability Program Director of the Defense for Children International, contends that these organizations have tried many times to give a hand in solving the different sensitive situations in Palestine. Yet the political parties, whether in the internal 
conflict or the confrontation with "Israel", have always put limits for them, as these parties always underestimate the civil society's role and even suspected it (personal communication, 02.01.2018).

Abu Eqtaish has highlighted several important points. He has pointed out the limits and the stumbling obstacles preventing civil society groups from achieving substantial change. They started to control their fund accounts harmed the effectiveness and quality of their work. They also put many checkpoints and divide the land. As Zaghal stated that the Israeli occupation limits the ability of civil society to access all beneficiaries; hence, for some civil society organizations to work in all the Palestinian cities, they have to operate through multiple offices in Gaza, the West Bank, and sometimes even in Jerusalem. Also, they have to acquire legal registrations from both the Palestinian and Israeli authorities (personal communication, 15.12.2017).

These circumstances certainly pressure the CSOs financially and politically pressures and would reduce the quality of their services due to the number of challenges they face. Second, some of the local NGOs intervened in the situation but the political views on these interventions are not taken as seriously as the involvement of political parties and factions. A reason for this situation might be that in the case of Palestine. The focal point lies in the political orientations and localizing groups of interests within the public concern. However, at this point, Gramsci's theory explains how these civil society organizations were made only to help in improving the situation without making any political steps or affiliations. On the other hand, CSOs were not as powerful as expected or pretended to be in actual life.

Therefore, the involvement of civil societies as an effective tool for social and political change has to be further debated and discussed in a more specific and narrow context. Hadeel Elayan from Sawa Organization states that Sawa organization doesn't have a role in the political field. However, its main role is aiding those in need including women, children, and families of the victims and who have been harmed because of the occupation and the internal division (personal communication, 01.02.2018). Elayan further says, civil society's work is related to services and consultation but they have no realpolitik. Moreover, Abu Eqtish has also stated Defense of Children International in Palestine (DCIP) in 2014 started a campaign to hold accountable the occupation forces in the UN for using children as human shields in wars and armed clashes. However, and for the first time, the Secretary-General has refused the recommendation of his representative for such a request after the declaration of the initiative of the DCIP Organization to protect the children in Palestine by using the political terms and legal mandate the UN put. Hence, civil society has not taken a useful role in resolving the causes of political causes due to the political obstacles and challenges by powerful institutions (personal communication, 02.01.2018). 


\section{Debates on Political Division by Palestinian Civil Society:}

The leaders and activists of civil society in Palestine unanimously agreed that political fragmentation caused significant damage to the Palestinian system at political, social, and cultural levels. Such damage has weakened the presence of Palestine cause in international forums and organizations. Such bad ramifications are reflected in the culture of people and their concepts of mutual peaceful coexistence (Ogretir, 2008). The division harmed the composition of Palestinian life in connection with social emancipation and economic developments.

Civil society played a limited but constructive in the issue of national reconciliation and the subject of peaceful resistance to the occupation. The civil society provided more than one initiative, but they sometimes lose influence since there is parts of Palestinian society that limit their connections to the political parties.

Since the beginning of the political split in 2007, civil society has openly and actively expressed its dissatisfaction and rejection of the phenomenon of national tragedy. The nonviolent nature of the Palestinian resistance has reached its climax during the $21^{\text {st }}$ century (Ozcelik, 2020). The network of NGOs, including the networks in the West Bank and Gaza Strip as well as parliamentary blocs and the participation of some political parties, formed the Committee on Public Freedoms. It focuses on human rights abuses in both the West Bank and Gaza, including political arrests, the closure of civil institutions, and the assault on certain peaceful activities (personal communication 09.05.2018).

The deep causes of the problem were not analyzed as an entry point for reconciliation and the political division was not treated as a reason to undermine the Palestinian political system. Articles 44, 45, and 46 of the Palestinian Basic Law (temporary Palestinian constitution) emphasize the components of the political regime as a presidential system. However, it became a mixed system after the division in which two heads of power (the president and the prime minister), might complicate the democratic nature of future Palestine state, especially in the absence of the Legislative Council and the containment of the judiciary (personal communication, 13.05.2018).

It seems apparent that PSC has no solid collective plan, which determines who the organizations are, what their objectives, and how they want to achieve them. There is no vision regarding the political system and the state. Although the role of civil society is limited since it is not part of the process and political structure, it has excellent opportunities to achieve a positive impact on national reconciliation. Experience has shown that this moral force of civil society is not negligible if it manages its activities adequately. The leaders of civil society organizations emphasize the significance of establishing internal peace of the community for more than reconciliation efforts. The contribution of civil society institutions to the issue of reconciliation is limited and non-effective in the real sense. As a result, these institutions fall outside the framework 
of the political system in broader terms. The inability of the Palestinian Authority to achieve national goals and the delay in peacemaking may provide an opportunity for civil society organizations to make a change (personal communication, 06.05.2018).

The two groups (Fatah and Hamas) make tangible efforts to create a special civil society that suits the regime of security which controls the lives of citizens as well as the economic and social organizations. Some civil society leaders spoke of the absence of the efficient role of the Palestinian civil society in reconciliation efforts. Democracy in public life declined dramatically including in public bodies such as local government municipalities, student councils, and trade unions. The civil society worked in a dualtrack strategy to end the political split. The essential elements of this strategy are to encourage the masses to take over the streets in protest and to document the violations of human rights and basic liberties (personal communication, 07.05.2018).

The masses lost confidence in the political parties and institutions of civil society are living in a state of self-confidence to achieve their true values and traditions. At the same time, civil society institutions could not be deepening their ability to mobilize the public quickly through the student councils and social movements. They suppose, I mean PCS, to work to construct a community alliance for the sake of putting pressure on both conflicting groups to come closer towards reconciliation.

The leaders of civil society have moved away from the masses and their social engagements. Civil society did not provide creative solutions on the grassroots level to deal with the political division. The ongoing Fatah and Islamist discourse does not raise to the level required to deal with the conflict in a much more innovative way. Civil Society needs to be more pragmatic and realistic when it comes to putting its strategies of making internal and domestic peace at the political level. Civil society needs to play all the roles that would make changes in the balance of power and rearrange the map of interests strategically and rationally to transform the conflict.

\section{Initiatives of Palestinian Civil Society in the Context of Peace-Building and Reconciliation}

The Palestinian civil society has undertaken numerous efforts and initiatives in the issue of political split and the subsequent reconciliation file but the tangible results on the ground as we already discussed in the previous pages were limited and ineffective.

- Initiatives aiming at ending the division and breaking the siege on Gaza Strip as well as organizing and supporting international solidarity campaigns and returns hips aimed at breaking the siege. The failure of the peace process undermined all efforts to develop programs for the people on a much more professional basis (personal communication, 28.04.2018).

- Among the successes achieved by the society is the initiative of reducing the effects of division in some areas. Its most valuable success addresses the human 
rights violations resulting from the division, including arbitrary detention, torture, dismissal from public office, infringement of freedom of expression, peaceful assemblies, and the right to form associations (personal communication, 29.04.2018).

- Civil society interventions also included pressures to protect humanitarian interventions and follow up the catastrophic humanitarian consequences of the return of health, water, and basic services. There have been modest initiatives and contributions by the civil society to the reconciliation process, but although these contributions had positive impacts on the situation, they could not gain the requisite strength. However, some of these initiatives were affected by the political framework and by the state of containment and cooptation. However, only a limited number of institutions remained independent (personal communication, 28.04.2018).

- The most important initiative is the Palestinian National Initiative (Mubadara) 2006-2007 which participated in the Cairo negotiations and was included in the Palestinian Non-Governmental Organizations Network (PNGO). It aimed at solving the problem of the health sector by the PNGO. Certainly, there are initiatives to communicate with institutions, international parties, and organizations which are working on the issue of reconciliation.

- The youth movement took over the streets in an attempt to end the division under various names such as "Youth of March 5", "Youth of June" and "Youth Movements". At the same time, joining with some civil institutions to bring about positive changes in the Palestinian society. It hopes to play a pivotal role in ending the split with the minimum level of cost politically and socially (personal communication, 30.06.2018).

- The PNGO Network formed the Public Freedoms Committee, which aims at focusing on human rights violations in both the West Bank and Gaza. These violations include political arrests, closure of civil institutions, and attacks on Youth activists and volunteers. It hoped to end the division and the political split by formulating initiatives of mediation between the conflict groups. Thus, it has organized many networks, marches, and tents sit-in call for unity in 2011. At the time, it was able to influence the popular efforts and informed the President, Mahmoud Abbas, that he should visit Gaza for the sake of reconciling differences with Hamas. They told him that if he does so, he would be welcomed by Hamas and the political division will end and consequently, our national project would be revived.

- Panorama civil group has managed a program funded by the European Union to coordinate the efforts of all the institutions working on peace, health, education, and the environment in one strategic pot. It is crucial to invest in professional initiatives such as the Swiss Reconciliation Initiative, which still exists, and establish professional experience in the field of conflict resolution and peace studies. This professionalism includes theoretical orientations and practical skills that suit the Palestinian political and social context. It is useful to adopt a national program that neutralizes external intervention and start building bridges of trust with profes- 
sional negotiators and sharing the voice of academia and the private sector in the negotiation process (personal communication, 30.04.2018).

\section{Challenges and Obstacles}

The Palestinian civil society has not found its appropriate place against the backdrop of the Oslo Era. In other words, that requires the redefinition of the Palestinian civil society by the new changes of Oslo and its political, social, and economic milestones. Civil society does not have enough power to generate sufficient pressure on the parties to conflict regarding the division, its role has not much differed from those of political parties that were not part of the division but became partner parties in one degree or another over time. Besides, civil society still tries to play the role of reformer without sufficient force of the ground. When the split got deeper day after day, civil society emerged as one victim of such division. Division caused deterioration in the system itself to the extent that participatory democracy emerged on paper only without real substance.

Historically speaking, the roots of the problem traced back to the establishment $t$ of the National Authority which is an extension of the PLO. The structure of the organization focused on the widespread use of money and political influence to buy elites and prevent criticism including direct repression. Containment and cooptation were used widely to cultivate new leaders and new elites and civil society was not exceptional to that trend. Trade unions and student councils established inside the occupied territories were utilized by some political factions to falsify their representation among the masses.

Cultural elites, intellectuals, and writers were co-opted by the Authority by offering them posts in the government as ministers, deputy ministers, advisors, or ambassadors abroad. They have been privileged with huge salaries and covering other expenses. Additionally, the Authority transformed funding sources into a tool of control and influence over political parties and civil society. Popular unions such as teachers' unions and the syndicate of public servants were established but used also to look for funds and influence as well.

\section{Final Concluding Remarks}

The Oslo Agreement signed between the Palestinians and the Israelis in 1993 had impacted the background of civil society in Palestine due to the social, political, and economic changes that occurred in the Palestinian context. Civil society has not had enough power and willingness as well to put pressure on the two conflicting parties to end the status of political division and split. This is despite its role as reformer and peace promoter at least at the domestic level. At the more advanced stage, civil society activists felt victimized by this fragmentation because participatory democracy was unable to function at the system level and grassroots movements as well. 
The main reason behind such a problem was the Palestinian Authority's strategy of putting pressure on the international funds that go to the civil society sector, along with another strategy of containing and co-opting the elites of this sector by offering them portfolios and privileges. The Palestinian Authority has used the strategy of cooptation of civil and cultural elites especially writers, intellectuals, and activists by offering them good positions including ministries and public offices and paying them luxurious salaries.

It is almost impossible to achieve perpetual peace just only people-to-people processes or only formal agreements between conflicting parties. Structural violence and inequalities must be addressed as well. The Israeli-Palestinian peacebuilding requires multiple perspectives and solutions with complex thinking as well as cognitive, behavioral, and affective changes in multiple levels from interpersonal to global. Civil society has encountered some problems and hurdles in peacebuilding in the Israel-Palestine context. First, over the last half of the century, many conflict resolution and peace scholars, practitioners, and activitists have engaged in conflict resolution and peacebuilding activities. Although there has been no real huge conceptualization and theories on the subject, it has rarely reached ordinary people on psychological, social, cultural, educational, community, and developmental levels. Second, primary, secondary and third party conflict parties have lost their belief and enthusiasm in a concrete peace agreement. In the postSeptember 11 World, formal peace processes have failed and the conflict situation has worsened. Third, because of the intractable, protracted, and deep-rooted nature of the conflict, the conflict dynamics have escalated into more violence and armed conflict. The enemy images and other psychological processes have made grassroots and civil society peace activities useless and void (Chaitin, 2011).

To conclude civil society organizations can provide neutral information to conflicting groups based on professional and impartial sources. Appropriate and creative tools and channels for communication between both parties must be developed professionally. The urgent search for acceptable mediators, young energetic leaders, and a positive school of thoughts must be intensified. In sum, despite civil society in Palestine has encountered some setbacks and hindrances, there have been some hopeful developments in the third sector and grassroots and funding have risen in a considerable amount. When third sector and grassroots have been used effectively in the Middle East peace processes, it will have a strong impact on people-to-people peacebuilding and they will challenge the political-psychological-social status quo. Grassroots projects have different, creative, and interesting forms from education and counseling to arts and entertainment. Palestinians, Arabs, and Israelis are cooking, camping, sailing, cleaning beaches, climbing mountains, and coming together for conflict resolution and peace, young and old, male and female, students, and scholars. 


\section{References}

1. Falcitelli, G., \& Montanarini, G. (1999, August 30-September 8). Seminar on the NG0 contribution to the peace process. Summer school on the social and economics aspects of the Middle East Peace Process, Molfetta-Bari.

2. Bishara, A. (2012). Civil society: A critical study. Arab Centre for Research and Policy Studies.

3. Bloomfield, D., Barnes, T., \& Huyse, L. (2008).Reconciliation After Violent Conflict: A Handbook, Stockholm: International IDEA.

4. Bouris, D. (2014). The European Union and occupied Palestinian territories: Statebuilding without a State. Routledge.

5. Chaitin, J. (2011). Peace-building in Israel and Palestine: Social psychology and grassroots initiatives. Palgrave Macmillan.

6. Chaitin, J. (2012). Co-creating peace: Confronting psycho-social-economic injustices in the Israeli-Palestinian context. In B. Charbonneau and G. Parent (Eds.), Peacebuilding, memory, and reconciliation: Bridging top-down and bottom-up approaches (pp. 146162). Routledge.

7. Galtung, J. (1976). Three approaches to peace: Peace-making, peacekeeping, and peacebuilding. In J. Galtung (Ed.), Peace, war and defence: Essays in peace research (pp. 282-304). Ejlers.

8. Galtung, J. (1969). Violence, peace, and peace research. Journal of Peace Research, 6(3), 167-191.

9. Galtung, G. (2001). After violence reconstruction, reconciliation, and resolution. In M. Abu-Nimer (Ed.), Reconciliation, Justice and Coexistence: Theory and Practice (pp. 3-23). Lexington Books.

10. Ghali, B. B. (1992). An Agenda for Peace. United Nations Publication.

11. Lederach, J. P. (1995). Conflict transformation in protracted internal conflicts: The case for comprehensive framework. In K. Rupensingh (Ed.), Conflict Transformation (pp. 201-222). Macmillan.

12. Lederach, John. P. (2005). The Moral Imagination: The Art and Soul of Peacebuilding. Oxford University Press.

13. Leeuwen, M. (2009). Partners in peace: Discourses and practices of civil society peacebuilding. Ashgate.

14. Moughrabi, F. (1992). Israeli Control and Palestinian Resistance. Social Justice, Focus on Resistance, Rights, and Justice, 19(3), pp. 46-62.

15. Natil, İ., Pierobon, C., \& Tauber L. (2019). The power of Civil Society in the Middle East and North Africa: Peace-building, change, and Development. Routledge.

16. Ncube, C. (2000). Contesting Hegemony: Civil Society and The Struggle For Social Change in Zimbabwe, 2000-2008. A PhD thesis defended at the University of Birmingham.

17. Nobel Prize.org. (1992). The Nobel Peace Prize of 1992. Retrieved from https://www. nobelprize.org/prizes/peace/1992/press-release/. 
18. Ogretir, A. D. (2008). The Relationship between culture and the conflict resolution styles: A survey method and a statistical analysis. Middle-East Journal of Science Research, cilt 3, 2008, 96-104.

19. Ogretir, A. D. (2017a). Aggression theories revisited: Lorenz's neo-instinctivism, Wilson's socio-biology and Skinner's behavioral theories. Journal of Asian Scientific Research, 7(2), 38-45.

20. Ogretir, A. D. (2017b). Explanation and understanding of human aggression freudian psychoanalytical analysis, from neo freudian perspectives and bandura's social learning theory. International Journal of Social Science and Economic Research, 2, 21512164.

21. Ogretir, A. D., \& Özçelik, S. (2008). The study of ethnocentrism, stereotype and prejudice: Pscho-analytical and psycho-dynamic theories. Journal of Qafqaz University, 24, 236-244.

22. Öğretir, A. D., \& Özçelik. S. (2018). Şehitlik Eylemlerine veya İntihar Terörizmine Genel Bakış. In E. Efegil (Ed.), Dini Söyleme Dayalı Terörizmin Analizi (pp. 133-169). Gündoğan Yayınları.

23. Ogretir, A. D., \& Özçelik. S. (2017). İslami Barış Paradigması ve İslami Barış Eğitimi. Yeni Türkiye: Íslam Dünyası Özel Sayısı I, 95(23), 171-185.

24. Özçelik, S. (2005). Neorealist and neo-Gramscian hegemony in international relations and conflict resolution during the 1990s. Abant Izzet Baysal Universitesi-Iktisadi ve Idari Bilimler Fakultesi Ekonomik ve Sosyal Arastirmalar Dergisi, 1(2), 88-114.

25. Özçelik, S. (2017). İsrail-Filistin ve İsrail-Arap Çatışması, In S. Demir and O. Bingöl (Eds.), Yeni Ortadoğu: Aktörler, Dinamikler ve Denge Arayışları (pp. 117-163), Barış Kitap.

26. Özçelik, S. (2020). Will the Gandhian non-violence produce nonviolence peacekeeping: From Shanti Sena (Peace Army) to the Islamic nonviolence. International Journal of Politics and Security, 2(5), 71-93.

27. Palestine Liberation Organization Negotiation Unit. (2018). The Ongoing Nakbah. Negotiation Affairs Department.

28. Paffenholz, T. (2010). Preface civil society and peacebuilding: A critical assessment. Lynne Riener.

29. Pina, A. D., (2006). Report for Congress: Palestinian elections. Congressional Research Service.

30. Putnam, R. D. (2000). Bowling alone: The collapse and revival of American community. Simon and Schuster.

31. Schanzer, J. (2008). Hamas vs. Fatah: The struggle for Palestine. Palgrave Macmillan.

32. Sheikh Khalil. (2008). Nihad Palestinian reconciliation initiatives from June 2007 to June 2008. The Palestinian Centre for Consultancy and Conflict Resolution Beit Hikma.

33. UN. (2017). Peace Building Report. UN Publication House.

34. Wilde, G. (2014). Alexis de Tocqueville revisited: Between the centralization of political power, civil associations, and gender politics in the European Union. In M. Freise 
and T. Hallman (Eds.), Modernizing Democracy: Associations and Associating in the $21^{\text {st }}$ Century (pp. 31-44). Springer.

35. Wüstenberg, R. (2009). The political dimension of reconciliation: A theological analysis of ways of dealing with guilt during the transition to democracy in South Africa and Germany. Wm. B. Eerdmans Publishing. 